\title{
Merchant ships discharging unwanted marine species in close proximity of a French aquaculture area: Risks involved
}

\author{
Daniel Masson*, Gerard Thomas, Sylvie Genauzeau, Olivier Le Moine, Annick Derrien
}

Laboratoire Environnement et Ressources Poitou-Charentes, Station de Ronce les Bains, 17390 La

Tremblade, France

\author{
*: Corresponding author: Daniel Masson, tel.: +33 546762616 ; fax: +33 546762611 ; \\ email address : Daniel.Masson@ifremer.fr
}

\begin{abstract}
:
The most important oyster farming area in Europe is in a close proximity of two medium size merchant ports. Cargo ships deballast in this area before loading, releasing unwanted or noxious marine species. During a sampling campaign aboard these arriving ships, we found in some ballast water samples a huge number of potentially toxic dinoflagellates and some potentially pathogenic bacteria. A model was applied to find the potential geographical spread of the discharged ballast water. This model predicts the water to reach highly vulnerable shellfish farmed areas in six to eight days.
\end{abstract}

\section{Highlights}

A sampling campaign has been carried on ship's ballast water in La Rochelle port $\rightarrow$ The area is heavily shellfish farmed and thus highly vulnerable $>$ Some samples contained large number of potentially toxic dinoflagellates Mathematical model predicted the spreading of this released water to shellfish areas

Keywords : Ballast water ; Risk assessment ; Toxin producing dinoflagellates ; Shellfish farming ; La Rochelle ; Pathogenic bacteria 


\section{Introduction}

Ocean ships introducing invasive or noxious organisms in new areas by the way of released ballast water can have fatal effects both on coastal environment and public health (Carlton et al., 1993; Gollasch et al., 1998)

On the Atlantic coast of France, the port of La Rochelle imports more than 3 million tons and exports 2.3 million tons of goods per year, mainly cereals. Estimating $40 \%$ of loaded cargo as discharged volume, the total volume of ballast water released reach $920000 \mathrm{~m}^{3}$ per year in or around the port itself (Fig. 1) The BWDA model (David et al. 2012) give an estimation of $33 \%$ of cargo loaded; $40 \%$ is the estimate given to us by numerous ship masters.

The most important oyster farming area in Europe is located several miles to the South of La Rochelle, between Oleron island and the coast: 25000 tons of oysters are produced here annually, employing circa 6000 people with approximately 270 million $€$ turnover at maximum capacity. A large mussel cultivation area is situated to the North of the port. Cultivation practices for blue mussels comprise pole cultures ("bouchots") or long lines, producing circa 10,000 tons and employing around 500 people (approx. 30 million $€$ turnover; all these economic data in: Anonymous 2005). Therefore, these areas are particularly vulnerable to bacterial pollution or toxic phytoplankton blooms, which result in more and more, frequent closure of production areas (sales prohibitions), with bad economic consequences for this sector, not to mention public health problems when monitoring programs fail to detect them.

Two thirds of the ships arriving in La Rochelle for loading cargo are coming from Spanish and Portuguese coasts( Masson et al. 2000) where very frequent toxic algal blooms occur (Pazos et al. 1995), while others come from further away (South East Asia, America, Middle East), occasionally discharging ballast water containing exotic and noxious species (Masson et al., 2000; 2005).

To document this risk, several samples of ballast water were obtained in 2012 from ships arriving in the port for loading. As the main threats for aquaculture are pathogenic bacteria and toxin producing micro-algae, we focused on Vibrio genus for bacteria and potentially toxin producing phytoplankton species search. 


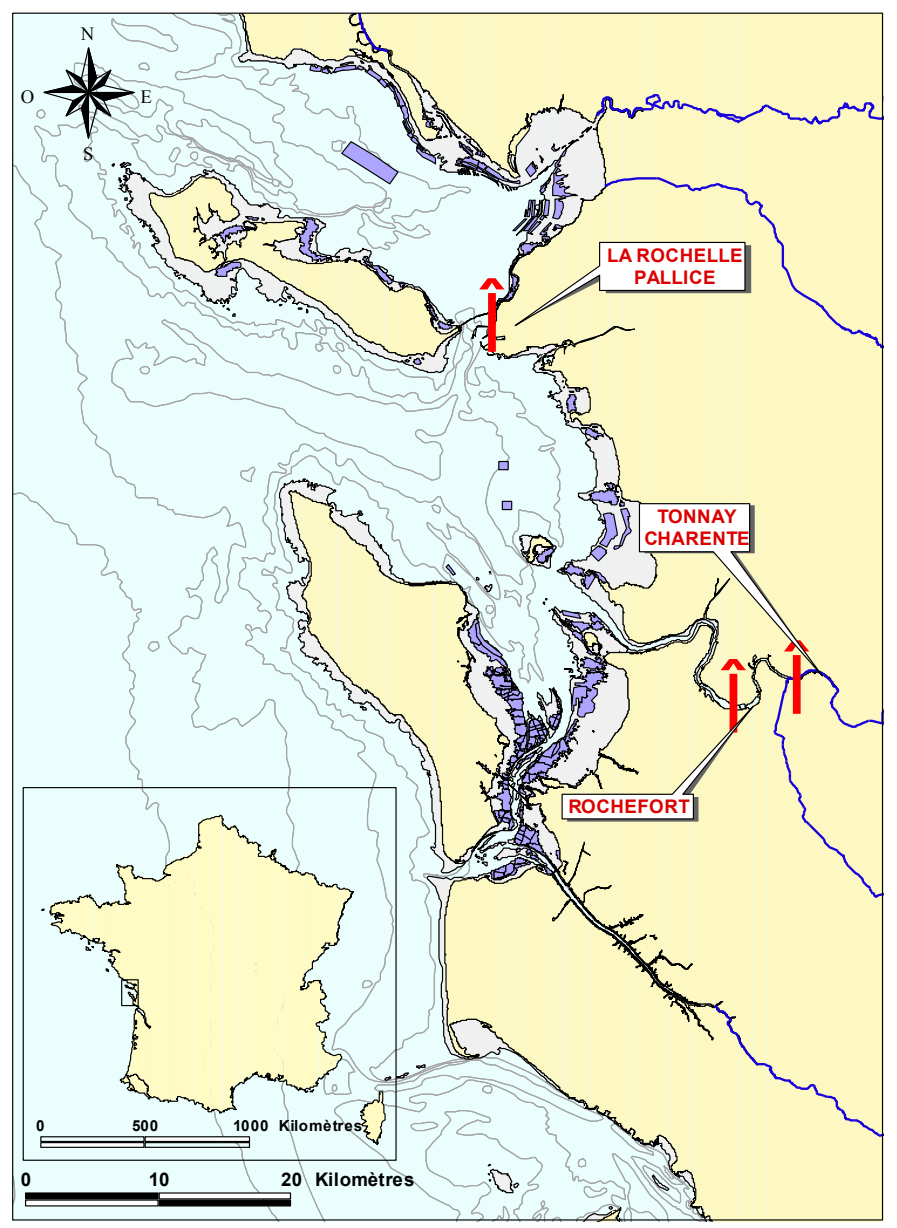

Fig 1: Mer des Pertuis area with Marennes -Oléron area (South)

Baie de l'Aiguillon (North) aquaculture areas (grey) (In gray) and the merchant ports (î)

\section{Material and methods}

Sampling aboard arriving ships in France has become more and more difficult with the years, due to the reluctant and distant ship owners. The best way is to see the shipmaster at arrival and ask for permission. As the ship's name remains confidential, permission to sample is generally granted.

\subsection{Ships}

Access given to the ships arrivals through the port's database, the ships interesting to sample were chosen considering the last port (Iberian peninsula, North Africa, or more remote), the cargo (preferably huge quantity of cereals aboard bulk carriers) and the more convenient time for sampling (when the ship is loading). In 2010, 17 ships, in 2011, 12 ships and in 2012, only 7 ships were sampled. 


\subsection{Sampling}

The sampling was generally carried in engine room by starting a ballast pump and opening the checking valve after ten minutes. Ten litres for phytoplankton and two litres (in sterile bottles) for bacteria research were taken in this case. These volumes seemed the most appropriate, according to David et al. (2007) Samples were always filtered (outside ship or in laboratory) at $20 \mu \mathrm{m}$ and lugol preserved when not immediately observed (see discussion below)

\subsection{Conditioning}

The samples (after recording temperature, salinity and water origin if known) were put in a black thermal box and driven to the laboratory 10 minutes away.

\subsection{Bacteria}

The genus Vibrio was specifically researched (after enrichment during 6 or $18 \mathrm{~h}$ at $41^{\circ} \mathrm{C}$ ) with TCBS and ChromAgar Vibrio media; suspicious colonies and some isolated strains were identified with API $20 \mathrm{E}$ galleries. Then, nucleic acids have been extracted and genetic amplification has been applied to detect the potentially pathogenic strains.

Vibrio parahaemolyticus (toxR gene), Vibrio vulnificus (vvhA gene) and Vibrio cholerae (16S23S RNA intergenic space) have been researched by PCR on nucleic acids in enrichment media and strains (Hervio-Heath et al. 2002, Deter et al. 2010)

\subsection{Phytoplankton}

Ten millilitre sub samples were put in observation chamber, let 3 hours for sedimentation then observed by inverted microscope (10 $\mathrm{ml}$ sedimentation chamber, Utermöl method). The count led to the estimate number of cells per litre. This procedure is consistent with the French phytoplankton-monitoring programme REPHY (Sournia ed., 1978)

Only exotic (non indigenous) or known producing toxins species were determined and counted. Among them, special attention was given to dinoflagellates and Pseudonitzschia genera, the later in two groups: large (seriata complex) or thin (delicatissima complex)

\section{Results}

\subsection{Phytoplankton (Table 1)}

In 2010 no potential harmful species were detected in the 17 samples taken outside ships at openings in hull during ballast discharges.

In the 12 samples taken in 2011, 11 contained Pseudonitzschia sp. And only 4 contained Dinophysis, mainly D.sacculus.

In 2012, Pseudonitzschia was present in 4 of the 7 samples. On the other hand, the various Dinophysis species (particularly those known as toxin producing like D.acuminata and D. sacculus) were present in almost all the samples. 
The most interesting results are the unusually high number (more than 200000 cells/litre) of Dinophysis (sacculus, acuminata, caudata, acuta) found in the ships coming from Pasajes and La Coruňa on April 13 and 16 2012, respectively. Some sampling campaigns had been carried previously aboard ships arriving in French ports (Masson et al., 2000). We never observed before such a quantity of cells, coming undoubtedly by pumping in a bloom at (or close to) the previous port(s).

\subsection{Bacteria (Table1)}

Some potentially pathogenic bacteria were also found: in the MA4 ship, coming from Algeria, Vibrio parahaemolyticus (in enrichment broth, tox $R$ gene) and V.vulnificus (in enrichment broth and strains, $v v h A$ gene) are present. On MA3 ship, (from Amsterdam), a 16S 23S RNA of $V$.cholerae was found by PCR in enrichment broth, without any certainty about pathogenic character, as non-O1 neither O 139. In MA2 ship from La Coruňa, V.parahaemolyticus was detected (in enrichment broth, tox $R$ gene)

\section{Discussion}

\subsection{Sampling}

The sampling was done through ballast pump checking valves, ten minutes after the start of the pump in order to avoid a possible bias (more concentrated sample at the beginning, as suggested by Gollasch and David, 2011), when the pumps had not already been on. In most cases, though, the ship was loading cargo and releasing ballast water at the same time, the pumps running since at least one hour.

Table I: sampling campaign in 2012

\begin{tabular}{|c|c|c|c|c|c|}
\hline $\begin{array}{l}\text { Ship code, } \\
\text { Length, } \\
\text { Dead } \\
\text { Weight } \\
\text { Tonnage }\end{array}$ & Coming from: & Sampling date & $\begin{array}{l}\mathrm{T}^{\circ} \mathrm{C} \\
\mathrm{S} \% \text { 。 }\end{array}$ & $\begin{array}{l}\text { Phytoplankton observation after } \\
10 \mu \mathrm{m} \text { filtration and concentration in } \\
\mathrm{NaCl} 35 \% \text { o solution }\end{array}$ & $\begin{array}{l}\text { Vibrio research on TCBS, } \\
\text { ChromAgar Vibrio media and } \\
\text { API20E gallery identification }\end{array}$ \\
\hline $\begin{array}{l}\text { MA1 } \\
\text { 180m } \\
\text { DWT: } \\
33500 t\end{array}$ & $\begin{array}{l}\text { Bejaia } \\
\text { (Algeria) }\end{array}$ & 28/03/2012 & $\begin{array}{l}15.5^{\circ} \mathrm{C} \\
36.2 \% \text { 。 }\end{array}$ & $\begin{array}{c}\text { Diatoms: Pseudo-nitzschia sp larges. } \\
\text { (seriata complex) } \\
\text { Dinoflagellates: Dinophysis (sacculus, } \\
\text { acuminata,) Ceratium, Prorocentrum } \\
\text { micans, Protoperidinium spp }\end{array}$ & $\begin{array}{l}\text { Chromobacterium violaceum, } \\
\text { pathogenic and opportunist germ } \\
\text { in tropical et subtropical areas }\end{array}$ \\
\hline $\begin{array}{l}\text { SP1 } \\
99 m \\
\text { DWT: } \\
5750 t\end{array}$ & $\begin{array}{l}\text { Port of } \\
\text { Pasajes } \\
\text { (Spain) }\end{array}$ & $13 / 04 / 2012$ & $\begin{array}{c}15^{\circ} \mathrm{C} \\
34.6 \% \text { 。 }\end{array}$ & $\begin{array}{l}\text { Diatoms: Pseudo-nitzschia sp larges. } \\
\text { (seriata complex): } 618 \text { cells / litre } \\
\text { Dinoflagellates: numerous Dinophysis } \\
\text { (sacculus, acuminata, caudata, acuta) } \\
\text { and Phalacroma: } 204443 \text { cells / litre, } \\
\text { numerous Ceratium (fusus, furca, } \\
\text { macroceros, lineatum), Protoperidinium } \\
\text { spp }\end{array}$ & $\begin{array}{l}\text { No Vibrio researched (too late for } \\
\text { beginning a culture) }\end{array}$ \\
\hline $\begin{array}{l}\text { MA2 } \\
\text { 125m } \\
\text { DWT: } \\
9822 \mathrm{t}\end{array}$ & $\begin{array}{l}\text { La Coruňa } \\
\text { (Spain) }\end{array}$ & $16 / 04 / 2012$ & $34.4 \%$ 。 & $\begin{array}{c}\text { Diatoms: Pseudo-nitzschia sp larges. } \\
\text { ( seriata complex) in small quantity } \\
\text { Dinoflagellates: numerous Dinophysis } \\
\text { (sacculus, acuminata) and Phalacroma: } \\
102770 \text { cells / litre, numerous Ceratium } \\
\text { (fusus, furca, macroceros, tripos), } \\
\text { Protoperidinium spp, Prorocentrum } \\
\text { micans. }\end{array}$ & $\begin{array}{c}\text { Vibrio vulnificus } \\
\text { Shewanella putrefaciens }\end{array}$ \\
\hline
\end{tabular}




\begin{tabular}{|c|c|c|c|c|c|}
\hline $\begin{array}{l}\text { AN2 } \\
107 m \\
\text { DWT: } \\
6918 t\end{array}$ & $\begin{array}{l}\text { Las Palmas } \\
\text { (Canarias) }\end{array}$ & $16 / 04 / 2012$ & $36.6 \%$ 。 & $\begin{array}{c}\text { Diatoms: Pseudo-nitzschia sp larges. } \\
\text { ( seriata complex), Coscinodiscus, } \\
\text { Paralia sulcata, Grammataphora } \\
\text { Dinoflagellates: Dinophysis (sacculus), } \\
\text { Phalacroma, Ceratium (fusus, furca, } \\
\text { macroceros, tripos), Protoperidinium } \\
\text { spp, Prorocentrum micans. }\end{array}$ & Nothing found \\
\hline $\begin{array}{l}\text { MA3 } \\
\text { 125m } \\
\text { DWT: } \\
9561 \mathrm{t}\end{array}$ & Amsterdam & 23/05/2012 & $\begin{array}{l}15.8{ }^{\circ} \mathrm{C} \\
8.2 \%\end{array}$ & $\begin{array}{l}\text { Numerous squeleton shaped } \\
\text { dinoflagellates (Ebriales) Not known as } \\
\text { toxic. Can be present in Atlantic and } \\
\text { Channel under } 17-18^{\circ} \mathrm{C}\end{array}$ & $\begin{array}{c}\text { Aeromonas hydrophila } \\
\text { Klebsiella terrigena } \\
\text { (not surprising with } 8.2 \% \text { o } \\
\text { salinity) }\end{array}$ \\
\hline $\begin{array}{l}\text { GE1 } \\
89 m \\
\text { DWT: } \\
4270 t\end{array}$ & $\begin{array}{l}\text { Bilbao } \\
\text { (Spain) }\end{array}$ & $14 / 06 / 2012$ & $\begin{array}{l}18.6{ }^{\circ} \mathrm{C} \\
33.3 \% \text { 。 }\end{array}$ & $\begin{array}{c}\text { Diatoms: Pseudo-nitzschia larges } \\
\text { (seriata complex) in huge quantity: } \\
144246 \text { cells / litre ballast water } \\
\text { Dinoflagellates: numerous Dinophysis } \\
\text { (sacculus, caudata, fortii) and } \\
\text { Phalacroma: } 5800 \text { Dinophysis sp /litre } \\
\text { ballast water }\end{array}$ & $\begin{array}{c}\text { No Vibrio researched (too late for } \\
\text { beginning a culture) }\end{array}$ \\
\hline $\begin{array}{l}\text { MA4 } \\
\text { 142m } \\
\text { DWT: } \\
\text { 13971t }\end{array}$ & $\begin{array}{c}\text { Oran } \\
\text { (Algeria) }\end{array}$ & 03/07/2012 & $\begin{array}{l}20.4{ }^{\circ} \mathrm{C} \\
35.6 \% \text { 。 }\end{array}$ & $\begin{array}{c}\text { Diatoms: very few diatoms } \\
\text { Dinoflagellates: numerous Dinophysis } \\
\text { (sacculus): } 1000 \text { Dinophysis sp / litre } \\
\text { ballast water }\end{array}$ & $\begin{array}{c}\text { Vibrio vulnificus } \\
\text { Vibrio mimicus (gastro entéritis) } \\
\text { Possibly Vibrio } \\
\text { parahaemolyticus }\end{array}$ \\
\hline
\end{tabular}

As we had generally a limited time aboard, only 10 litres for phytoplankton and 2 litres for bacteria research were taken. These volumes had been found the most appropriate, as also retained by David et al. (2007) all the samples came from double bottom ballast tanks.

The close proximity of port and laboratory allowed to filter (phytoplankton) and to begin the cultures (bacteria) at short notice.

\subsection{Phytoplankton results}

As a total flora determination and counting was time consuming and not relevant for risk assessment, we focused on known or potentially toxin producing species.

The huge quantities of Dinophysis sp found the April 13 and 16/ 2012 in ballast water taken in Pasajes and La Coruňa respectively, is demonstrative of the ability to survive a short travel ( Zvyagintsev et al., 2009) the cells being still alive even after the passage in high pressure areas in the pumps. As we know Galicia, Cantabria (B.Reguera, pers. com.) and southwest French coasts (up to Arcachon oyster farming area, $200 \mathrm{Km}$ north of Spanish border) were plagued by toxin producing dinoflagellate blooms at the same time, these ships pumped obviously their ballast water in blooms, in the last departure port or along the neighbouring coast. This is almost certain in the case of Passajes.

We were unable to measure the toxin level in these samples, but the toxicity of Dinophysis is highly probable, the Arcachon oyster producing area was closed for toxicity over regular threshold at that time, and also in most of the North West Spanish aquaculture areas too (Seoane et al., 2012). 


\subsection{Bacteria results}

We choose to watch for the Vibrio genus only: although Vibrio cholerae (var 01 and 0139 ) is specifically designated in the Ballast Water Management Convention, the interest in $V$.parahaemolyticus, V.alginoliticus and V. vulnificus, equally noxious for public health (sea food disease or skin illness) make sense (Hervio et al., 2002; Mc Carthy et al., 1994).

The results were not obvious, with the exception of V.vulnificus found in "la Coruňa" sample, and C. violaceum in "Bejaïa" (Algeria) waters.

None of them seems pathogenic this time.

Further studies on more numerous samples should be done to have a good idea of the risk involved (in sea food contamination particularly), perhaps looking for heterotrophic and sanitary indicative bacteria, as in Zvyagintsev et al. (2010)

\subsection{Risk assessment:}

The ships coming to ports of La Rochelle or Rochefort (some 20 miles south, in the Charente river estuary) are waiting the appropriate tide level or a place along a quay, in an assigned area between the isles of Ré and Oleron. As the place is well protected, number of the moored ships uses this area to discharge their ballast.

The GPS coordinates of a ship moored in this area and which had been discharging were registered and used further in a MARS 2D mathematical model to assess the released water trajectory.

The ship coming from La Coruña loaded 5000 tons of wheat. The reasonable estimate for the subsequent discharged volume is $40 \%$ of the dry goods loaded (and $30 \%$ for liquids), then $2000 \mathrm{~m}^{3}$ in this case.

The parameters used for a theoretical $2000 \mathrm{~m}^{3}$ release permitted to describe the trajectory of diluted water and suspended matters too (Fig.2)

This model is more simple than 3D model used by Brickman et al. (2007) on Easter Canadian coast but in a far smaller (and a shallow) area. 


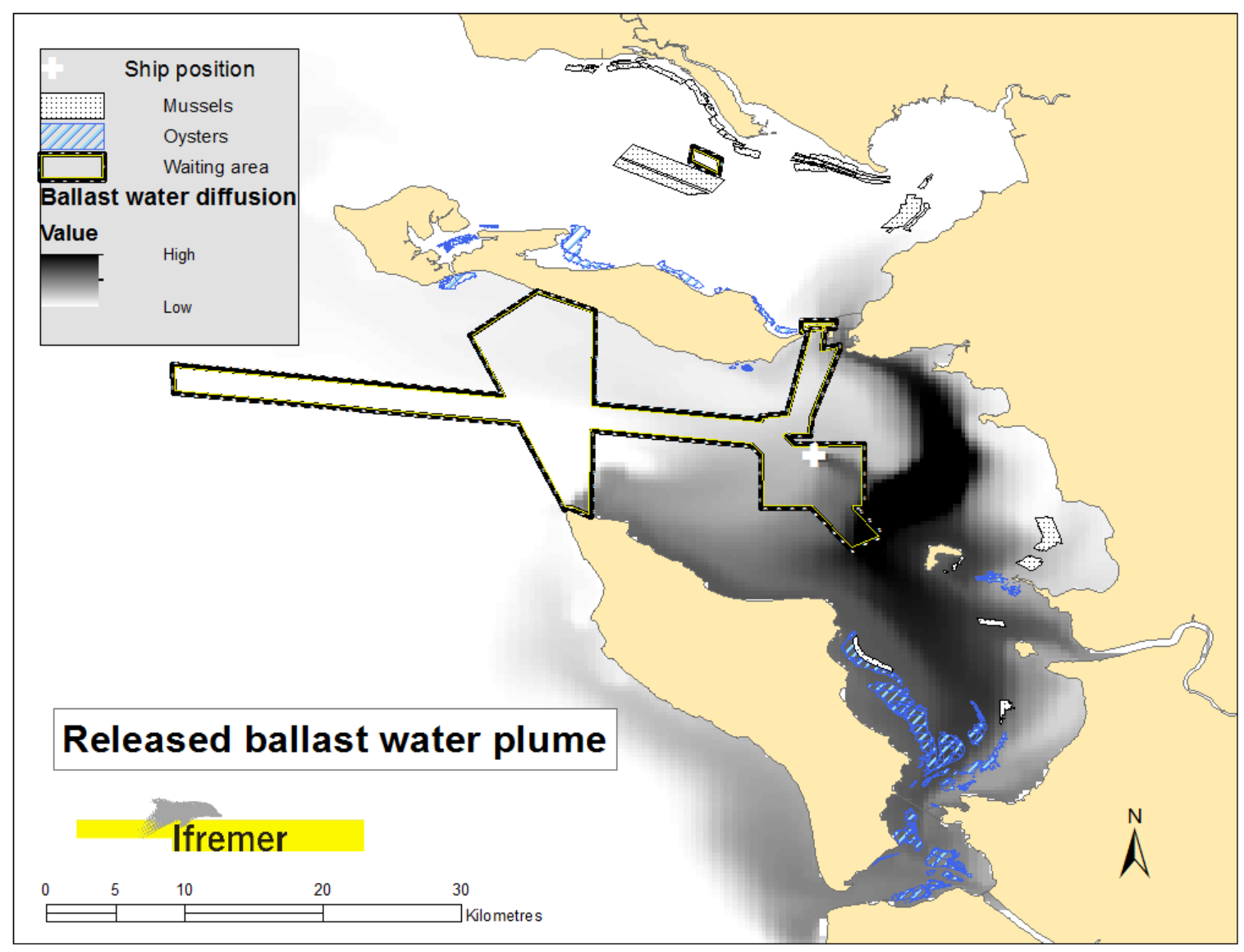

Fig 2: Spreading of ballast water from waiting area

The results are particularly worrying: in an 8 days time, the released waters reach the oyster beds and mussel longlines or mussel poles of Marennes-Oléron area. Any unwanted organism carried in these waters is spread away in this area.

In the April 13. 2012 example, we can estimate the number of Dinophysis cells spread in this area up to several billions, even if a sample bias is taken into account. As the statistical organisms distribution can most probably be described by a negative binomial function (organisms not dispersed at random but in aggregates, as suggested in Wright, 2012), the estimated number seems reasonable enough.

Some ships are discharging at the port entry (Fig.3). In this case, we can observe a different spreading: the released waters go North, and in the same amount of time spread on the mussel poles and mussel longlines in the Baie de l'Aiguillon and in the straight of Pertuis Breton respectively, very important mussel production areas. 


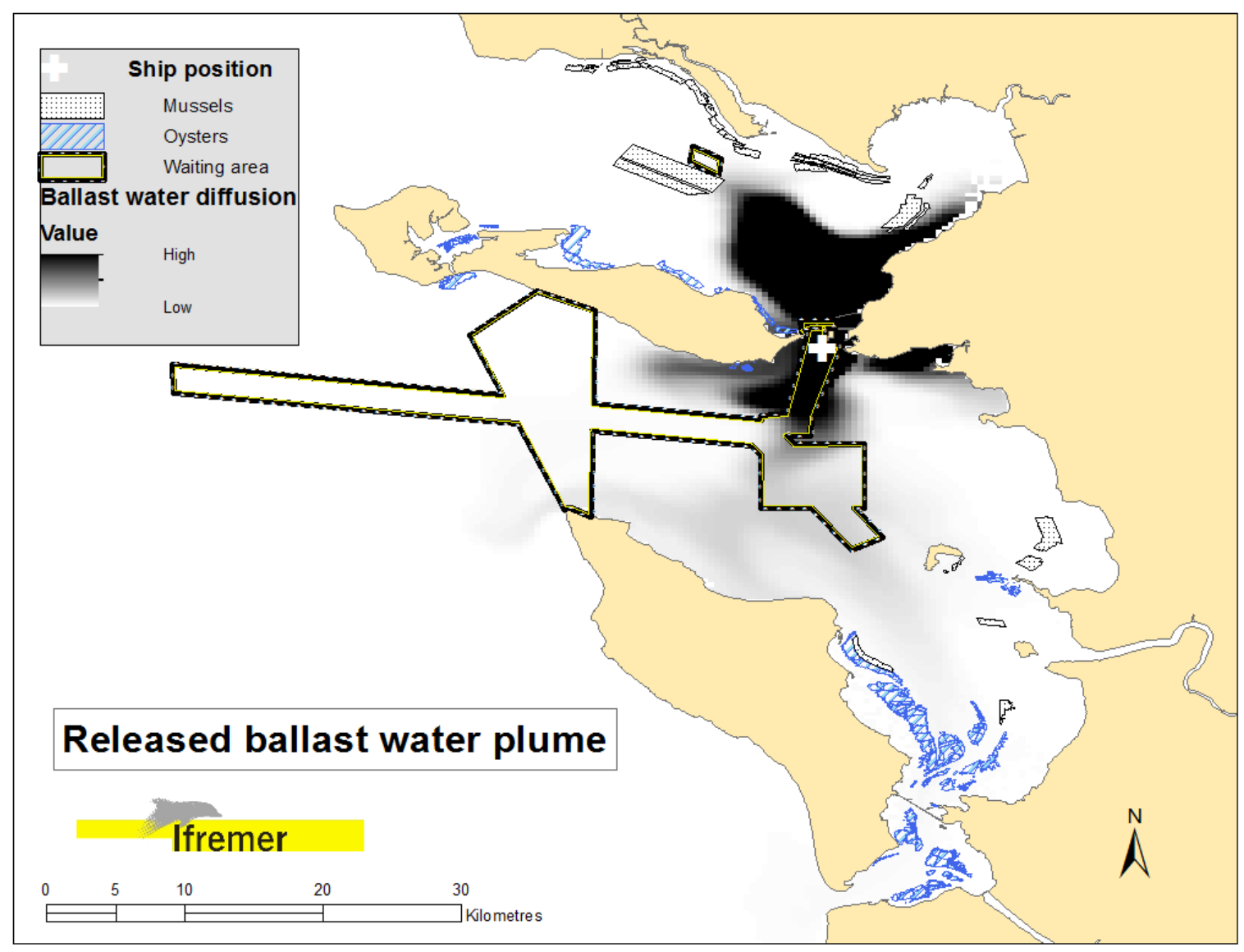

Fig.3: Spreading of ballast water from port entrance

Although we do not have definite and documented proof of noxious organisms introductions by ship's ballast waters in France, some cases are questioning:

- Toxin producing Alexandrium catenella appeared for the first time in the Thau lagoon area on Mediterranean coast, in 1993(Lilly et al., 2002): a bloom in the eastern part of the lagoon led to the temporary prohibition of oyster's sales in the area. Since then, several blooms have occurred with the same consequences. Genetic sequencing (ibid) gave an Asiatic origin of this strain; as the first blooming area in the lagoon was in close proximity of the channel connected with the merchant port, the introduction by ship's ballast water is highly probable.

-After the Xynthia storm (2010), a Pseudo-nitzschia australis toxin producing bloom occurred in the Baie de l'Aiguillon area (Nezan et al., 2010), probably induced by the post-storm environmental conditions (waters returning from flooded agricultural land) This species which have never been observed here before, occurred for the first time in Brest (Nezan et al. 2010) The same little bulk carriers coming from Spain come regularly in Brest and La Rochelle areas, probably introducing (and spreading) this species.

On April 2012, this release of several billions of Dinophysis cells in Marennes Oléron area (maximum estimate: 200 million cells $/ \mathrm{m}^{3}, 2000 \mathrm{~m}^{3}$ release in 1 billion $\mathrm{m}^{3}$, high tide, 120 coefficient) didn't start a bloom. But we can foresee occurrence of some other noxious species like Alexandrium or Heterosigma, already found in ship's ballasts in La Rochelle (Masson et al., 2000) Cysts production could lead to subsequent blooms there in the next years, may the environmental conditions become favourable. This way of introduction has been well described by Hallegraeff et al. (1991) 


\section{General conclusion}

These few samplings contain numerous potentially toxin producing phytoplankton species. For the first time in France, we found samples of ballast water obviously pumped in a potentially toxic bloom. A simulation of this discharge trajectory predicts a spreading on oyster and mussel farming areas and can be seen as an unacceptable risk by the shellfish farmers.

This far from exhaustive study was carried to document the risk involved by ship's ballast water discharging in this specific area. The most important oyster producing area in Europe, close to an important mussel farming activity, all highly vulnerable to toxin producing blooms and pathogenic bacteria contamination, deserved a particular assessment, intented first for the port authorities awareness.

Other aquaculture areas in France are in close proximity of merchant ports (around Loire estuary or in the bay of Seine for example), with the same risk. More studies should be necessary for the authorities general awareness, before entry in force of the Ballast Water Management Convention and its subsequent regulation constraints (risk management, training for enforcement procedures)

The French REPHY monitoring programme running since 1983 is particularly efficient to detect toxin-producing phytoplankton, non-indigenous species included. But this new parameter (ballast water discharge) deserves to be taken in account to improve the system.

\section{Acknowledgements}

This work was carried for the "Projet de Développement Durable"(sustainable development project) funded by the Poitou-Charentes Regional Council.

The authors wish to thank, J.P. Joly, P. Lassus, P. Hess and C. Bechemin, IFREMER senior scientists, for their corrections and remarks. And A. Fillon for filling the gaps.

\section{References}

Anonymous 2005 Recensement de la conchyliculture 2001; Agreste: la statistique agricole; Ministère de l'Agriculture, de l'Alimentation, de la Pêche et de la Ruralité; www.agreste.agriculture.gouv.fr

Brickman, D., Smith, P.C. 2007 Variability in invasion risk for Ballast Water Exchange on the scotian Shelf of Eastern Canada; 2007 Marine Pollution Bulletin 54, pp 863-874

Carlton, J.J. and Geller, J.B. 1993 Ecological Roulette: the global transport and Invasion of Nonidigenous Marine Organisms; Science, 1993 vol 261 pp 78-82

David, M. and Percovic, M. 2004 Ballast Water sampling as a critical component of Biological Invasions Risk Management Marine Pollution Bulletin 2004, vol 49 pp313-318

David, M., Gollasch, S., Cabrini, M., Perkovic, M., Bosnjak, D., Virgilio, D. 2007 Results from the first Ballast Water Sampling study in the Mediterranean S. The port of Koper Study Marine Pollution Bulletin: 54 (2007) pp 53-65 
David, M., Perkovic, M., Suban, V., Gollasch, S. 2012 A generic ballast water discharge assessment model as a decision supporting tool in ballast water management. Decision Support Systems 53 (2012) p 175-185

Deter J., Lozach S., Veron A., Chollet J., Derrien A. and Hervio-Heath D. 2010. Ecology of pathogenic and non-pathogenic Vibrio parahaemolyticus on the French Atlantic coast. Effects of temperature, salinity, turbidity and chlorophyll a. Env. Microbiol. 12 (4) : 929-937.

Gollasch, S. 1998 Removal of barriers to the effective Implementation of Ballast Water control and Management Measures in Developing Countries GEF/IMO/UNDP 1998

Gollasch, S., David, M. 2011 Sampling Methodologies and Approaches for Ballast Water Management Compliance Monitoring Traffic and Transportation vol 23, 2011, $\mathrm{N}^{\circ} 5$ pp 397405

Hallegraeff, G., Bolch, J.C. 1991 Transport of Toxic Dinoflagellate Cysts via Ship's Ballast Water Marine Pollution Bulletin, 1991, vol 22 №1

Hervio-Heath, D., Colwell, R.R., Derrien, A., Robert-Pillot, A., Fournier, J. -M., and Pommepuy, M. 2002. Occurrence of pathogenic vibrios in coastal areas of France. $J$ Appl Microbiol 92: 1123-1135.

Lilly, E.L., Kulis, D.M., Gentien, P., Anderson, D.M. 2002 Paralytic shellfish poisoning toxins in France linked to human introduced strain of Alexandrium catenella from the western Pacific: evidence from DNA and toxin analysis. J Plankton res 24, 443-452.

Mc Carthy, S., Khambaty, F. 1994 International Dissemination of Epidemic Vibrio cholerae by Cargo Ship Ballast and Other Nonpotable Waters.Applied andEnvironmental Microbiology, July 1994, p 2597-2601.

Masson, D. Courtois, O. Masson, N. Guesdon, S. Rocher, G. 2000 Ballast water research in France current status communication, ICES Annual Science Conference, Bruges, 27-30 sept 2000, p196

Masson, D., Piquet, J.C., Courtois, O. 2005 Survival of Bacteria and Phytoplankton in Ship's Ballasts Marine Science and Technology for Environment Sustainability third international conference acts, ENSUS 2005,p 43-49

Nezan, E., Chomerat, N., Bilien, G., Boulben, S., Duval, A., Ryckaert, M. Pseudo-nitzschia australis on French Atlantic coast-an unusual toxic bloom 2010 Harmful Algae News, $\mathrm{N}^{\circ} 41$, April 2010

Pazos, Y., Figueiras, F.G., Alvarez-Salgado X.A., Rosen, G. 1995 The control of succession in red tide species in the Ria de Arousa (NW Spain) by upwelling and stability. Harmful Marine Algal Blooms. Lassus et al. Ed; p 651-656

Seoane, S., Orive, E. 2012 First report of Dinophysis acuminata bloom in Basque waters, Northern Spain Harmful Algae News, N 46/2012

Sournia, A. 1978 Phytoplankton manual, UNESCO, ISBN 93-3-101572-9, 337p.

Stachowicz, J.J., Byrnes, J.E. 2006 Species diversity, invasion success, and ecosystem functionning: disentangling the influence of resources, competition, facilitation and intrinsic factors Marine Ecology Progress Series 311: 251-262 
Wright, D.A. 2012 Logistics of compliance assessment and enforcement of the 2004 Ballast Water Convention. Journal of Marine Engineering and Technology, Vol $11 \mathrm{~N}^{\circ} 2$ January 2012

Zvyagintsev, A.Y., Ivin, V.V., Kashin, T., Orlova, V., Selina, M.S., Kasyan, V.V., Korn, O.M., Koprnienko, E.S., Kulikova, V.A., Bezverbnaya, I.P., Zvereva, L.V., Radashevsky, V.I., Belogurova, C.S., Begun, A.A., Gorodkov, A.N. 2009 Acclimatation and Introduction of Hydrobionts Ship's Ballast Water Organisms in the port of Vladivostok Russian Journal of Marine Biology 2009 vol. 35 Nº pp 41-52

Zvyagintsev, A.Y., Selifonova J.P. 2010 Hydrobiological studies of the Ballast Water of Cargo Ships in Russian Sea Ports Okeanologia 2010 vol. 50 Nº 6 pp 973-981 